\title{
Investigation of the Knowledge and Views of Seventh Graders on the Relationship between Space Research and Technological Developments
}

\author{
Salih Gülen \\ Child Development, Malazgirt Vocational School, Muş Alparslan University, Mus, Turkey
}

Copyright $\mathrm{C} 2019$ by authors, all rights reserved. Authors agree that this article remains permanently open access under the terms of the Creative Commons Attribution License 4.0 International License

\begin{abstract}
The main purpose of this study is to examine the views of seventh grade students on the relationship between space research and technological developments. The mixed method was used in the research. The true-false test was used to collect quantitative data. Qualitative data were collected through a fully structured interview form. Homogeneous samples were used in the study involving 134 participants. The research was conducted with 7 th grade students in a public school in the Eastern Anatolia Region during the 2018-2019 academic years. Data were analyzed with the help of Microsoft Excel programs. Descriptive and content analysis and a technique such as frequency and percentage were used. With the interpretation of the findings, it was found that seventh grade students had very good knowledge about space research and technological developments. Students argue that space research has an impact on technological developments; technological research also has an impact on space exploration. Suggestions are presented in line with the results obtained.
\end{abstract}

Keywords Space Research, Technological Developments, Seventh Grade, Knowledge, Views

\section{Introduction}

The mystery of space has attracted people since ancient times. Mankind has developed various technological tools with a sense of curiosity regarding the stars or the visible universe. In time, the speed of the space exploration, which is aimed at determining the mystery of the universe, has increased with the help of technology, which is quickly developing (Aktamış, Acar and Hiğde, 2018). Technological and exploratory innovations, which are continuing at full speed, are thought to continue until the discovery of different places where life exists. Probably will never be a stop.

There has been a slow growth in the education on this subject since elementary school years in order to take steps in space research and technological developments on the future generations. Although this education begins within the family environment with students asking their first questions, unfortunately, many families do not have any scientific knowledge about space research and technological developments. According to the Ministry of National Education (MoNE) (2018), the science curriculum provides 92 hours of space training (third grade 9 , fourth grade 15 , fifth grade 24 , sixth grade 14 , seventh grade 16 and eighth grade 14 hours). Space-related issues are available at all grade levels. However, there are space researches and technological developments which are only available at the seventh-grade level. Within this training, there are topics such as stars, planets, satellites, seasons and movements (Arkkurt, Durukan and Şahin, 2015). In addition, seventh grade students learn 8 hours of space research and technological developments. According to the MoNE (2018: 39), the seventh graders learn to gain knowledge and skills about the contributions of space research by considering the importance of the telescope in terms of the importance of astronomy and the importance of technology in the subject.

Space research has begun with the curiosity of people from very old times. Many interesting events such as moon and solar eclipses, stellar shifts, celestial rocks and comets appear to be quite mysterious (Babaoğlu and Keleş, 2018). In addition to the Egyptian, Mesopotamian and Greek civilizations, the space explorations in which the people of Islam and the western world started with various studies continue rapidly (Unat, 2009). Nowadays, researchers are continuing with new works and studies every day. Space exploration undoubtedly influences many fields of study. NASA, which is the focus of space research, has so far issued 1,800 products and received 6300 patents. It has contributed to many areas ranging from smoke detectors to 
athletic shoes, from bioreactors to heart surgery lasers (Teker Yelkenci, 2017). Undoubtedly, these studies are important for the development of humanity. These developments also give hope to the new generations and allow looking into the future with more meaningful eyes. In addition, this situation allows students to pay attention to science and space related issues (Trumper, 2006).

The most fundamental assurance of space research is technological developments. The term "technology", which consists of the words of art and knowledge in Greek, originates from the word techno-logia. While Tehnikos mastery refers to technical knowledge, logia means art, science and talent (Dursun and Özmen, 2018; Gülen and Demirkuş, 2018). It is what human beings do to make life easier through utilizing science (Ayvacı and Ayaydın, 2018). So with the simplest and most descriptive definition, technology can be expressed in this way. Technology; it is seen as the ability and knowledge necessary for the production of auxiliary tools and equipment for people's needs and requirements (Bacanl1, 2018). People work intensively in the construction of technological tools. The construction of a new technological vehicle in line with a goal or purpose has become easier today (Yıldız, 2018). There are more exciting developments especially in the field of space technologies.

Space technologies serve all kinds of purposes such as communication, defense and astronomy. Spacecraft design, launching, orbit placement and useful data transfer (Günaydın, Çetindamar, Karaata and Kalemci, 2009). Today, space and aviation technologies are used in many areas ranging from aircraft and defense systems, communication, energy, agriculture and astronomy studies for transportation and security purposes (Bayraktutan and Bidırd1, 2015; Yıldırım Becerikli, 2013). One of the most sought-after criteria for vehicles designed to explore space is weight. The weight of a vehicle affects many aspects of its take-off, landing and fuel. Another aspect of space technology is the cost of technological tools. Due to the impact of many elements, the most used parts of the whole product increase the cost. Nano technology products help to reduce both weight and cost in space technologies. Due to the tensile strength of steel nanostructures Nano tubes, both cost and weight are greatly reduced (Özdogan, Demir and Seventekin, 2006; Unal and Yarman 2014). In fact, Nano technology can be produced in such a way that the ultra-vertical, ultra-fine fabrics and astronauts are able to move more easily in space (Celep and Koç, 2008). Developments in space technologies give hope for future space research.

Essentially, it is possible to say that both technological developments and space research are affected by the needs and curiosity. People's curiosity and willingness to solve the mystery, over time, as a new and advanced instrument of others emerges. An exploration of space brings up a new question, a new curiosity and a new need. Some deliberate or coincidental discoveries in technology lead to another study. As a result, both developments are in parallel and affect one another (Gülen, 2018).

In this study, the views of seventh grade students on this subject were applied. In general, in the literature, it is possible to come across numerous studies related to science and space concepts. Although the majority of these studies are related to misconceptions, it is possible to come across success, opinions or ideas (Arıkurt, Durukan and Şahin, 2015; Babaoğlu and Keleş, 2018; Bektaşl1, 2013; Plummer, 2008; Trumper, 2006; Türk and Kalkan, 2018). The difference between this study and other studies in question is seen as an irony; do spaces researches affect technological developments or do technological developments affect space research? This is determined according to the student. It is thought that these findings will benefit the area.

\section{Purpose of the Research}

The main purpose of this study is to examine the knowledge and views of seventh grade students on the relationship between space research and technological developments. In this context, the answers to the following questions were sought:

1. What is the level of knowledge of seventh graders regarding space research and technological developments?

2. Does space research affect technological developments, or do technological advances affect space research according to seventh graders?

\section{Method}

The mixed method was used in the research. The mixed method aimed to close the deficiencies in the solution of the research problems using both qualitative and quantitative data (Büyüköztürk, 2009; Creswell, 2013; Çepni, 2010). Qualitative data were collected together along with quantitative data.

\subsection{Participants}

Homogeneous (analogous) samples were used in the study. The aim of the analogous sample is to determine the status of groups of similar characteristics in a subject in order to effectively collect the data (Yıldırım and Şimşek, 2013). The research was conducted with 7 th grade students in a public school in the Eastern Anatolia Region during the 2018-2019 academic years. A total of 134 students participated in the study, depending on the volunteerism principle. 134 participants answered the true-false test and 123 participants participated in the fully structured interview form. Because 11 students were found to leave the form blank; they were not processed. The socio-economic status of the participants was similar. The 
majority of the parents are farmers. Farming involves animal feeding and agricultural activities at a level that only meets their needs. Only barley and wheat are grown as agricultural products. Very few of the parents of participants were shopkeepers. None of the participants had a higher income. The district where the study is conducted is quite rare. This district is steep and mountainous in eastern Anatolia. Students living in this area are not allowed to go to the planetarium, cinema or big cities. They are able to learn technology and space developments from television, books and teachers. They do not have a research center or science center or university to explore. Therefore, the study was conducted with these students. In addition, in the beginning of the 2018-2019 academic years, the participants conducted research on space research and technological development. This topic has been discussed and learned in class.

\subsection{Data Collection Tools}

The true-false test was used to collect quantitative data (Ed 1). Qualitative data were collected through a fully structured interview form.

In the fully structured interview form, the following questions were used.
1. Does your sense of curiosity towards space influence the development of technology? Explain with examples.

2. Does the development of technology influence space research? Explain with examples.

3. How do you think people conduct space research?

\subsection{Analysis of Data}

Data were analyzed with the help of Microsoft Excel programs. Descriptive and content analysis and a technique such as frequency and percentage were used.

Each true-false test items was evaluated as ten points according to the percentage distribution. There are 10 items in the test. $100 / 10=10$ because each student has 10 points for the correct.

The data of the fully structured interview form were analyzed both in terms of descriptive and content in order to determine the students' thoughts about space research and technological developments. The data obtained by both analysis methods are presented in the findings section.

The score range of the true-false test was evaluated according to the criteria given in Table 1 . In this table, the values are given according to the number of points.

Ed 1. True-false test items

\begin{tabular}{|c|l|c|c|}
\hline \multirow{2}{*}{ Order } & $\begin{array}{l}\text { Dear students, I would like to gather information about space exploration and technological } \\
\text { developments. This information will be used in a scientific study. Notes will not be evaluated. I just want } \\
\text { you to answer the questions asked based your knowledge. Participation is voluntary. Thank you... }\end{array}$ & True & False \\
\cline { 2 - 4 } & Items & T & F \\
\hline 1 & Scientists are doing research to solve the mystery of space. & & \\
\hline 2 & Space exploration is carried out only in observatories. & & \\
\hline 3 & There are man-made satellites in space. & & \\
\hline 4 & Telescope is an indispensable tool in space exploration. & & \\
\hline 5 & Our country has a communication satellite in space. & & \\
\hline 6 & The satellites whose duty period has expired lead to air pollution. & & \\
\hline 7 & There is no astronomer in the field of space exploration in Turkish history. & & \\
\hline 8 & Thanks to the development of technology, space exploration is facilitated. & & \\
\hline 9 & Due to the curiosity towards space, the development of some technological tools has accelerated. & \\
\hline 10 & People have not set foot on any celestial body. & & \\
\hline
\end{tabular}

Table 1. Interpretation range of scores

\begin{tabular}{ccc}
\hline Order & Value & Range for True-false test \\
\hline 1 & Very bad & $00.01-20$ \\
\hline 2 & Bad & $20.01-40$ \\
\hline 3 & Middle & $40.01-60$ \\
\hline 4 & Good & $60.01-80$ \\
\hline 5 & Very good & $80.01-100$ \\
\hline
\end{tabular}


As seen in Table 1, five equal intervals were determined for a more precise interpretation. According to this, it is very bad, bad, middle, good and very good value for the true-false test. Kandemir (2015) has similar criteria to this table.

\section{Reliability and Validity}

Within the scope of the reliability studies, the status of the sample group was explained in detail, the existing roles were explained, the conceptual framework, data collection and analysis were presented. In addition, these data were supported by descriptive analysis and content analysis (Glesne, 2013). The fully structured interview form used is based on expert opinion. The analyses received help from the teachers. In addition, the Cronbach's Alpha value of true-false test was calculated as 0.70 .For the coding and scoring, reliability was calculated by using the formula of Miles and Huberman (1994). According to this calculation, $90 \%$ confidence coding was performed throughout the study. In fact, according to Miles and Huberman (1994) 80\% and above has been accepted as reliable (Arik and Yilmaz, 2017). In the descriptive and content analysis of the validity of the research, direct quotations were given, and the accuracy of the research results was shown (Merriam, 2013). The codes used in the content analysis and the interpretations were completed in depth. In addition, subject gains were taken into consideration in terms of the scope validity of the true-false test. The true-false test was conducted with the researcher and lesson teacher. In the preparation of the test, the gains of the subject were taken into consideration. True and false numbers were tried to be kept equal. The same responses were avoided in a row. Validity values such as structure and appearance are obtained by seeking expert opinion (Yıldırım and Şimşek, 2013).

\section{Findings}

The findings of the study are presented below:

The mean score, standard deviation of the true-false test and the value range corresponding to these scores are given in Table 2.

Table 2. True-false test statistical values

\begin{tabular}{ccccc}
\hline Test & N & Standard deviation & Average & comment \\
\hline True-false test & 134 & 18.28 & 81.05 & Very good \\
\hline
\end{tabular}

Table 2 shows the average and standard deviation of the students who took the correct-false test. In addition, it is understood that these average scores are very good within the scope of the criteria in Table 1. Accordingly, the mean score of the participants was 81.05 and the standard deviation was 18.28. Table 3 presents the statistical data of respondents' responses to space research and technological developments.

In Table 3, space researches are given to the subjects that the technology has been developed or space researches have been made as a result of the development of technology. Accordingly, there are 89 participants $(72.36 \%)$ who think that research into space has an impact on the development of technology. 102 participants $(82.93 \%)$ support the idea that the development of technology affects space research. There are also participants who were opposed to both ideas and participants who participate in both at the same time. Some of the participants answered both questions at the same time, while some answered only one. Some of them did not answer any of them. Therefore, the number of participants varies.

Table 3. Statistical data of participants on space exploration

\begin{tabular}{lcccc}
\hline \multirow{2}{*}{ Substances } & \multicolumn{2}{c}{ Yes } & \multicolumn{2}{c}{ No } \\
\cline { 2 - 5 } & Frequency (f) & Percent (\%) & Frequency (f) & Percent (\%) \\
\hline Research into space influences the development of technology. & 89 & 72.36 & 13 & 10.57 \\
\hline The development of technology influences space research. & 102 & 82.93 & 9 & 7.32 \\
\hline
\end{tabular}

Table 4. Most repeated activities

\begin{tabular}{clcc}
\hline Order & activities & Frequency (f) & Percent (\%) \\
\hline 1 & Curiously & 42 & 34.15 \\
\hline 2 & Using Telescope & 30 & 24.39 \\
\hline 3 & Using Observatory & 27 & 21.95 \\
\hline 4 & With the help of spacecraft & 25 & 20.33 \\
\hline 5 & Doing research & 17 & 13.82 \\
\hline 6 & Using artificial satellites & 16 & 13.01 \\
\hline 7 & Using technological tools & 12 & 9.76 \\
\hline 8 & Going into space & 11 & 8.94 \\
\hline
\end{tabular}


The data of the most repetitive activities obtained as a result of the descriptive analysis are shown in Table 4.

According to Table 4, the most repeated activities in the scope of the activities that can be done for the space exploration of the participants were presented. Although the maximum frequency about curiosity is understood in Table 4, the majority of the activities show that space exploration can be made via technological developments. Accordingly, the participants stated that researches can be made using spacecraft, telescope or observatory. Content analysis from the participants' views is presented below.

\subsection{Space Research Affects Technological Development}

Under this theme, it is stated that the research conducted by the participants towards the space affects the technological developments.

\section{Curiosity}

The citations in this category are presented below. Quotations were randomly selected.

As people wondered about space, telescope was developed and observatories were established (P14).

For example, Galileo found the telescope. Scientists who were curious about the space became good at developing it (P46).

People have been able to come to these places because of their feelings of curiosity. Technology has been developed for something that people are curious about (P65).

Nowadays, people still wonder. For instance, people wouldn't have explored space if they didn't wonder. This is proof of this (P69).

The more a person is curious about space, the more research is done (P99).

People quickly invent inventions to learn about space (P102).

According to the quotations above, it is stated that technological developments occurred due to reasons such as people's sense of "curiosity" towards space and their willingness to gain "information" about space. Galileo's discovery of the "telescope", the creation of "new inventions" and technological "instruments" by people are given as examples. As is understood from these quotations, technological developments have accelerated due to people's sense of space.

\subsection{Technological Developments Affect Space Research}

Under this theme, it is stated that participants' technological developments affect space research.

\section{Technological developments}

The citations in this category are presented below.
Quotations were randomly selected.

If we didn't invent the telescope, how would we study the stars? (P26).

The development of technology facilitates space exploration (P39).

If more of the current rockets are sent out into space, we can find the mysteries in space (P46).

With the development of technology, many new things emerged and the unknowns of the universe appeared slowly (P65).

If technology didn't develop, we wouldn't have that much information. I think if we didn't have technology, we wouldn't have learned space research (P112).

Space probes and many other things influence the development of space research (P127).

As understood from the quotations, thanks to the "development" of technology, space exploration has been "easy". The study of "stars" with the invention of the "telescope", the development of technology to understand the "mystery" of the universe and the acquisition of "new" information is given as an "example". In general, the participants stated that due to the development of technology, researches about space were easily done. Apart from these findings, no explanation was given by the participants who said "no". However, a student stated that the development of technology "paralleled" the development of space (P131). According to this finding and the data in Table 3, it can be said that some participants think that both developments affect each other. As a matter of fact, it was determined that most of the participants said yes to both developments.

\section{Discussion}

It can be said that the students had a very good level of knowledge of space research and technological developments according to true-false test point averages. As a matter of fact, it is understood that the mean score of students in the true-false test is 81.05 and this grade is "very good" within the criteria of Table 1. Similarly, Özcan and Yilmaz (2018) determined that there are changes in the concepts related to space after the activities carried out in their studies. In addition, Gülen and Demirkus (2014b) have determined that the materials used in the study have positive effects on students' space-oriented concepts. In addition to these studies, Özdemir, Ayvaz and Poyraz (2003) found that students had a good level of knowledge. Birgün and Gürbüz (2008) determined that students' level of knowledge is not at a good level.

While $82.93 \%$ of the students think that space researches are affected as a result of the development of technology, $72.36 \%$ of them think that the researches towards space 
affect the development of technology. As a result of the development of technology, the majority of the students stated that space researchers have developed. However, when asked about the developments or how they were made, $34.15 \%$ of the students expressed curiosity about space. Apart from this, the students who are the experts of the telescope invention, satellites, observation houses, etc., are in the majority. However, each group of these students addressed a different technological impact. In addition, as a result of the content analysis, nearly half of the students stated that technological developments gained speed due to people's sense of curiosity towards space. Of course, the other half of the students stated that due to the development of technology, space research is easier. In the meantime, the point should not be forgotten that the majority of students did advocate both views. No studies related to space and technology was found in the research. Similarly, Arıkurt, Durukan and Şahin (2015) found that seventh graders generally consider astronomy as space research. In the study of Özsevgeç, Aytar, Çelik and Topakgöz (2018), they determined that the majority of students' explanations about space were planets and stars. Gülen and Demirkus (2014a) emphasized the importance of visual material in the training of space-oriented concepts. In addition, Babaoğlu and Keleș (2018) discovered that students were learning new concepts in terms of space. Finally, Ayvac1, Bülbül, Özbek and Ünal (2018) observed differences in student views about space.

\section{Conclusions and Recommendations}

It has been determined that seventh grade students have very good knowledge about space research and technological developments according to true-false test point averages. This result is thought to be the effect of the true-false test. In similar applications, the effect of this test can be observed experimentally.

Students were explored that space research indicates that technological developments influence space exploration. In other words, space researches and technological developments have been identified as interrelated and parallel elements. In order for similar results to be achieved at other grade levels, posters or catalogs of space explorations made through the innovations and technological developments that humanity brings to space research can be displayed in the classrooms.

\section{REFERENCES}

[1] Aktamış, H., Acar, E. \& Hiğde, E. (2018). Should we learn astronomy - explore space, change students' conceptual knowledge about astronomy? Kastamonu Education Journal, 26(2), 523-533. doi:10.24106/kefdergi.389816
[2] Arık, S., \& Yilmaz, M. (2017). Attitudes of science teachers towards environmental problems and their metaphorical perceptions for environmental pollution. Kastamonu Education Journal, 25(3), 1147-1164.

[3] Arıkurt, E., Durukan, Ü. G., \& Şahin, Ç. (2015). Developmental analysis of the views of students at different learning level on the concept of astronomy. Amasya University Journal of Education Faculty, 4(1), 66-91.

[4] Ayvac1, H. Ş., \& Ayaydın, A. (2018). Science, technology, engineering, art and mathematics (Edtr; Çepni, S.) STEM training from theory to practice. Ankara: Pegam training.

[5] Ayvac1, H., Bülbül, S., Özbek, D., Ünal, S. (2018). A study on the change of mental models: The concept of space.Journal of Yüzüncü Yll University Faculty of Education, 15 (1), 1355-1391.

[6] Babaoğlu, G., Keleş, Ö. (2018). Determination of 6th grade students' perceptions of the concepts of "star", "planet" and "moon, sun and earth". Karaelmas Journal of Educational Sciences, 6, 127-145.

[7] Bacanl1, H. (2018). Social skills training. Ankara: pegem academy.

[8] Bayraktutan, Y., \& Bidırd1, H. (2015). Policy perspective on technology and development plans in turkey. Kocaeli University Journal of Social Sciences, 29, 37-55.

[9] Bektaşl1, B. (2013). The effect of media on preservice science teachers' attitudes toward astronomy and achievement in astronomy class, The Turkish Online Journal of Educational Technology, 12(1), 139-146.

[10] Birgün, O., \& Gürbüz, R. (2008). Examining the level of knowledge of the teacher candidates about assessment and evaluation. Selcuk University Journal of Social Sciences, 20,135-162.

[11] Büyüköztürk, Ş. (2009). Manual of data analysis for social sciences. Ankara: Pegem Academy.

[12] Celep, Ş., \& Koç, E. (2008). Nanotechnology and its application areas in textile. Cukurova University Institute of Science, 17(7), 43-52.

[13] Creswell, J.W. (2013). Qualitative research methods (Trans. Ed.: Whole, M., \& Demir, S.B.). Ankara: Political Publications Distribution.

[14] Çepni, S. (2010). Introduction to research and project work. Trabzon: Celepler Printing.

[15] Dursun, B., \& Özmen, N. (2018). The views of science teacher candidates on the nature of science and technology. - Journal of Educational Sciences Research, 8(1), 55-71.

[16] Glesne, C. (2013). Introduction to qualitative research (Trans. Ed .: Ersoy, A., \& Yalcinoglu, P.). Ankara: An1 Publishing.

[17] Gülen, S. (2018). Determination the effect of STEM-integrated argumentation based science learning approach in solving daily life problems. World Journal on Educational Technology: Current Issues, 10(4), 95-114.

[18] Gülen, S., \& Demirkuş, N. (2014a). Effect of visual material on student achievement. Saarbrücken: Scholars Books Turkey. 
[19] Gülen, S.,\& Demirkuş, N., (2014b). The effect of visual material on student achievement in the solar system and beyond: space puzzle unit. Journal of Yüzüncü Yıl University Faculty of Education, 11(1), 1-19.

[20] Gülen, S., \& Demirkuş, N. (2018). A study on virtual course material design. 1th International Turkish-Russian World Academic Researches Congress, 14-16 December, Ankara, Turkey.

[21] Günaydın, H., Çetindamar, D., Karaata, S., \& Kalemci, F. (2009). Roadmap for aerospace and aerospace technologies. Ankara: TÜSİAD-Sabancı University Competition Forum

[22] Kandemir, M. A. (2015). Examining reflective thinking tendency levels of primary school mathematics and classroom teacher candidates according to some variables. Education Sciences, 10 (4), 253-275.

[23] Merriam, S. B. (2013). A guide for qualitative research design and implementation (Trans. Ed .: Turan, S.). Ankara: Nobel Publishing.

[24] Miles, B. M., \& Huberman, A. M. (1994). Qualitative data analysis (2nd ed.). London: Sage Publication.

[25] Ministry of National Education (MoNE), (2018). Elementary and Secondary School 3, 4, 5, 6, 7 and 8 grades science curriculum. Ankara: MoNE publications

[26] Özcan, H, Y1lmaz, S . (2018). Investigation of the preservice science teachers' astronomy conceptions via planetarium trip. Necatibey Faculty of Education Journal of Electronic Science and Mathematics Education, 12 (1), 392-418. DOI: 10.17522/balikesirnef.437815

[27] Özdemir, L., Ayvaz, A., \& Poyraz, Ö. (2003).The level of knowledge of students in cumhuriyet university about the sexually transmitted diseases. Cumhuriyet University Faculty of Medicine Journal 25 (1): 10 - 14.

[28] Özdoğan, E., Demir, A., \& Seventekin, N. (2006). Nanotechnology and its applications in textile industry. Textile and Apparel, 3, 159-168.

[29] Özsevgeç, T., Aytar, A., Çelik, F., Topakgöz, N. (2018). The views and beliefs of secondary school students about celestial bodies and life in space. Journal of Education and Society Studies, 5 (1), 247-264

[30] Plummer, J. (2008). Students' development of astronomy concepts across time, Astronomy Education Review, 7(1), 139-148.

[31] Teker Yelkenci, A.F. (2017). Spinoffs-Outputs of space technology. Date of access: 18.01.2019, http://www.astrobilgi.org/dosyalar/

[32] Trumper, R. (2006). Teaching future teachers basic astronomy concepts - seasonal changes- at a time of reform in science education, Journal of Research in Science Teaching, 43(9), 879-906.

[33] Türk, C., \& Kalkan, H. (2018). Teaching seasons with hands-on models: model transformation. Research in Science \& Technological Education, 36(3), 324-352. https://doi.org/10.1080/02635143.2017.1401532.

[34] Unat, Y. (2009). The development of astronomy. Astronomy teacher seminars, 26-28 August, Cide. Date of access: 18.01.2019, http://www.astrobilgi.org/dosyalar/
[35] Ünal, A.N., \& Yarman, B. S. B. (2014). Cyber space factor in determining the elements of national power. 7th International Conference on Information Security and Cryptology. October 17-18, Istanbul, Turkey

[36] Yildırım Becerikli, S. (2013). Communication differences between generations: a focus group study through science, technology and innovation news. Journal of Selcuk Communication, 8(1), 5-18

[37] Yıldırım, A. \& Şimşek, H. (2013). Qualitative research methods in the social sciences. Ankara: Seçkin Publishing.

[38] Yild1z, A. (2018). Industry 4.0 and smart factories. Sakarya University Journal of the Institute of Science and Technology, 22 (2), 546-556 